\title{
The financing of renewable energy development projects in Ukraine
}

ABSTRACT: The article aims to explore the determinants of the process of attracting financial resources for implementing renewable (alternative) energy development projects in Ukraine. The authors review and systematize the sources of funding and innovative financial instruments available for developing renewable energy sources (RES) in developing countries. Based on this, a pool of financial resources/RES development tools available for investment in Ukraine has been formed. It is proposed to build a model of the optimal structure of sources of financing renewable energy development projects. The research is founded on the forecasted schedule for increasing the share of RES in the national energy balance of Ukraine up until 2035. The limitations are connected with the lack of factual data on sources/instruments of funding in the field of RES. The model enables the prediction of the amount of funds that need to be allocated to finance renewable energy development projects, while optimizing the structure of their potential funding. The originality/value of the article lies firstly in the innovative application of the optimization model for forecasting the aggregate structure of funding sources in the energy sector; secondly, in the possibility of testing the model in practice and monitoring RES development projects in the territorial communities of the

$\bowtie$ Corresponding Author: Svitlana Orestivna Kropelnytska; e-mail: skropelnytska@gmail.com

1 Department of Finance ; Project and Educational Centre „Agents of Changes” PNU, Vasyl Stefanyk Precarpathian National University, Ukraine; ORCID iD: 0000-0003-4992-9550; e-mail: skropelnytska@gmail.com

2 Department of Corporate Finance and Controlling, Vadym Hetman Kyiv National Economic University, Ukraine; ORCID iD: 0000-0001-9153-8460; e-mail: mayorova@kneu.edu.ua

2021. The Author(s). This is an open-access article distributed under the terms of the Creative Commons Attribution-ShareAlike International License (CC BY-SA 4.0, http://creativecommons.org/licenses/by-sa/4.0/), which permits use, distribution, and reproduction in any medium, provided that the Article is properly cited. 
Carpathian region of Ukraine on the basis of the project-educational center for the development of innovations and investments in the region; thirdly, the proposed model can be used in the activities of state authorities and institutions of Ukraine for forming the policy of supporting alternative energy development projects.

KEYwORDS: renewable energy development projects, financial resources, financial instruments, renewable energy sources

\section{Introduction and literature review}

The strategic goal of most developed economies is to ensure energy independence, including the intensive increase of their own resource base, in particular by reducing or abandoning the use of traditional energy sources and growing the percentage of the energy obtained from RES. Interest in the search for alternative energy sources (AES) has manifested itself as a result of the global climate change. The United Nations Conference on the Environment on 16 June 1972 in Stockholm (UNCHE 1972) recognized the global nature of the world's environmental problems and stressed the need to create effective international mechanisms to improve the environmental situation.

The key priority among the Sustainable Development Goals by 2030, adopted at the UN Conference in 2015 (UN 2015), is a significant increase of the specific weight of renewable energy in the world energy balance, as well as the intensification of international collaboration aimed at facilitating access to scientific and technical activities in the sphere of the RES.

A significant achievement in the sphere of RES was founding the International Renewable Energy Agency (IRENA). The main purpose of IRENA as an intergovernmental organization is to provide support to various countries that are building a sustainable energy future. It is a key international platform for cooperation in the field of RES and a center of innovative experience, as well as a treasure trove of knowledge on policy, new technologies, resources and the implementation and operation of RES.

According to the IRENA (IRENA 2009), alternative energy sources include: bioenergy, geothermal energy, hydropower, ocean energy (tides, wave and heat), solar energy and wind energy. These AES are used on the basis of natural conditions. Therefore, the possibilities for their use in different countries are varied and depend upon: water resources required for the operation of hydropower; the availability of biomass from crop volumes required for bioenergy; the availability of geothermal sources necessary for the operation of geothermal energy; solar energy required for the operation of solar power plants and other sources that constitute renewable energy. Experts estimate (IRENA 2021) that the renewable energy projects implemented in 2020 will reduce expenses in the electricity sector by at least $\$ 6$ billion a year in developing countries compared to the introduction of the same amount of the fossil-based-fuel generating capacity. Two thirds of this amount will be saved through onshore wind systems, while other 
savings will be provided by hydropower and solar photovoltaic systems. The cost reductions are complemented by economic benefits and reduced carbon emissions. The $534 \mathrm{GW}$ of renewable energy that has been introduced in lower-cost developing countries since 2010 compared to the cheapest coal-fired option reduces electricity costs by around $\$ 32$ billion annually. Overall, the renewable electricity costs have decreased sharply over the past decade. The reasons for this phenomenon are: (a) the continuous improvement of technologies; (b) economies of scale; (c) competitive supply chains; (d) advanced developer skills (Fig. 1).

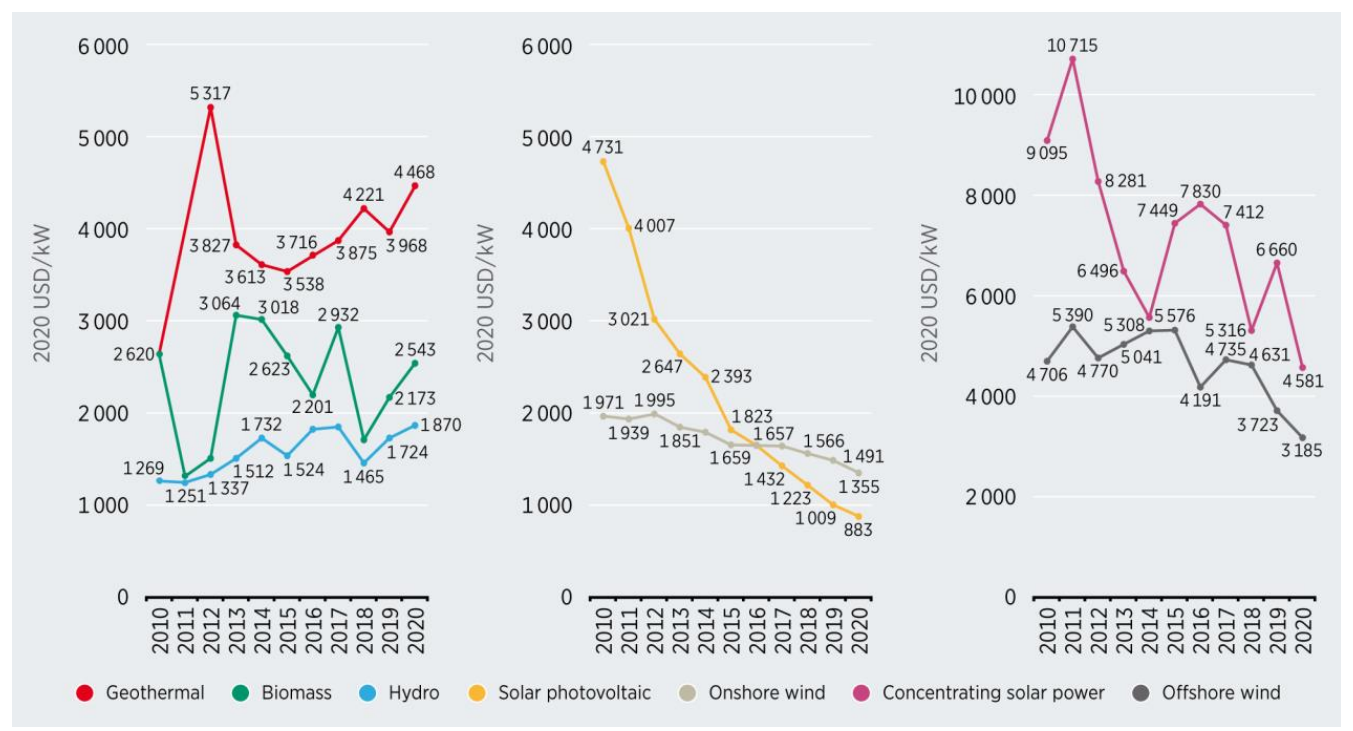

Fig. 1. The weighted-average total costs for the installation by technologies in the global dimension (for the period 2010-2020)

Source: IRENA 2021

Rys. 1. Średnie ważone całkowite koszty instalacji według technologii w wymiarze globalnym (dla okresu 2010-2020)

The issues of financing renewable energy development projects are also actively considered in EU countries. In 2009, a new directive on the promotion of RES was approved by the European Parliament (DEPC 2009). This directive has become a key document in the RES field in the EU, which defines the energy strategies of the participating countries. It sets binding national targets that predict the share of energy from RES in its total consumption. It is important for EU countries to find sources of funding for the implementation of RES development projects. In September 2020, within the framework of the Clean Energy Package, the European Commission adopted the regulations establishing a mechanism for financing RES (EU 2020/1294). The regulation aims at encouraging EU countries to co-operate by joining forces to both fund and deploy alternative energy projects. It is expected that such cooperation will increase the alternative energy share to $32 \%$ in the gross indicator of final electricity consumption by 2030 . According to the REFM, the European Commission determines the level of support and allocates grants to 
alternative energy projects for each project individually. The projects will be (a) located in those EU countries that have expressed interest in providing their territory for the physical location of stations, and (b) built with funds from other EU countries that have expressed a desire to contribute financially to such projects, thus increasing the share of alternative energy of their country.

Unfortunately, Ukraine cannot directly receive funding under the REFM Program. It can only be involved as a third party if all the criteria are met. Some of the key criteria are guarantees of the origin of electricity and their recognition by the EU and Ukraine at the same time. According to the Memorandum of Understanding between Ukraine and the EU on cooperation in the energy sector of 24 November 2016, Ukraine as a transit country plays an important strategic role. Additionally, the European Union's strategy places greater emphasis on the Ukraine's potential as a priority energy and communication link in the East, given that the interests of some of the more influential EU member states dominate over the commonly identified development vectors. Therefore, the issue of finding additional sources of funding for the RES development projects in Ukraine is extremely relevant.

\section{Research into problems of financing alternative energy development projects in Ukraine}

The implementation of alternative energy projects in developing countries, including Ukraine, is becoming especially timely today, and the problem of forming financial resources for their financial support is particularly acute.

Ukraine has approved the energy strategy "Security, Energy Efficiency, Competitiveness" (CMU 2017) for the period up to 2035. According to this strategy, it is planned to increase RES production in Ukraine from 3\% in 2015 to $12 \%$ by 2025 and increase this figure to $25 \%$ by 2035 (Fig. 2).

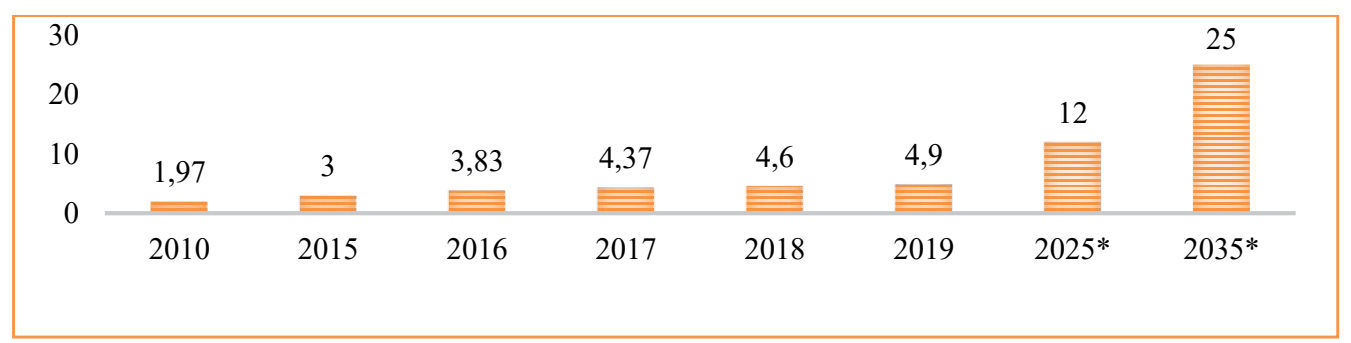

Fig. 2. Energy supply share from renewable sources in the overall structure of energy supply in Ukraine [\%] Source: own study based on (CMU 2017, UNDPU 2015, SSSU 2021, 2025*, 2035* - forecast data (CMU 2017)

Rys. 2. Udział dostaw energii ze źródeł odnawialnych w ogólnej strukturze dostaw energii na Ukrainie [\%] 
However, this growth directly depends on political stability in Ukraine, the legal environment and access to international funding. Until now, the growth has been largely due to the green tariff adopted in 2008 , which, by the end of 2029 , guarantees the prices for electricity obtained from renewable energy production facilities commissioned by the end of 2019 .

In recent years, Ukrainian scientists have been actively researching the problems of AES development in Ukraine. We consider the most important research, including: energy poverty in Ukraine in a pandemic caused by the coronavirus crisis (Goncharuk et al. 2021); guidelines for the alternative energy development in Ukraine until 2030 (Bilyavs 'ky ' $j 2020$ ); budget financing of energy projects (Zhyber and Solopenko 2020); risk management of the energy policy of developing countries (Nyenno et al. 2020). The development of RES has also been studied by KPMG Ukraine (KPMG 2019). However, the problems of finding new tools for financing renewable energy development projects in Ukraine and methods for their optimization remain unexplored.

Unfortunately, Ukraine is not experiencing the best times in the field of RES today. The COVID-19-impacted period of 2020-2021 can be referred to as years of survival and struggle in conditions of total non-payment for the supplied "green" electricity and quarantine restrictions for business. In addition, the market still suffers from a huge debt to RES producers. During 2020 , the state enterprise "Guaranteed Buyer" owed more than UAH 23 billion to the owners of the RES generating stations (RE 2020).

In addition, there are challenges in identifying common approaches to reforming Ukraine's renewable energy support system, meeting Ukraine's international climate policy commitments, and preparing for the implementation of the carbon border adjustment mechanism (CBAM) under the EU Green Deal (UE 2021).

Thus, the public financial instruments not only fail to contribute, but also significantly inhibit the formation of the investment potential for the future development of the production potential of RES producers.

At the same time, it is worth paying attention to other sources of financing for RES development projects in Ukraine, among which the EBRD's program for financing alternative energy in Ukraine USELF in the form of a credit line of up to EUR 50 million (USELF 2018) occupies an important place. USELF provides loans for the production of electricity from renewable sources such as water, wind, biomass, solar energy, as well as assistance in the development of projects that meet financial, technical and environmental criteria.

Other government funding sources - the Warm Credits program (SAEE 2021), grant funding from the State Regional Development Fund - are also not always attractive to RES producers due to the complicated system of project documentation preparation and the lack of additional conditions for obtaining such funding.

In this regard, it would be appropriate for Ukraine to take into account the experience of world leaders in financing alternative energy development projects. One of the common methods of financing RES development projects is the creation of energy cooperatives. In this case, the experience of Germany would be relevant (FMEAE 2015). There are associations of citizens, businesses and organizations that implement various local projects in the field of AES development. Such associations focus on decentralized, environmentally friendly and independent ener- 
gy production from companies and concerns. The energy cooperatives meet their own energy needs for energy production, and the surplus is sold to the grid using the rules of the "green tariff".

Especially popular today are "green bonds", which are debt instruments to raise funds for projects to develop renewable energy, energy efficiency and clean transport. Such Euro bonds are traded on average twenty-five basis points lower than the equivalent ordinary bonds. This shows that financial institutions highly value the prospects of alternative energy and are ready to finance projects aimed at preserving the environment and having a positive impact on it. Poland's experience in placing "green" bonds will be useful for Ukraine (SG 2019).

Large long-term infrastructure projects and the design and construction of RES development facilities can be implemented by the project financing scheme. The importance of such a financial instrument as project financing in the implementation of alternative energy development projects is proven in the study of Bjarne Steffen (Bjarne 2018). In this scheme, the functions of financing and construction of an alternative energy facility (as well as its operation for the first few years) are entrusted to a specially created project company. The state's interest in the project may be manifested in facilitating its implementation through the provision of indirect guarantees and the purchase of an option to purchase an alternative energy facility after a certain period.

Crowdfunding platforms (Nigam et al. 2018; GF 2020) can be used among the innovative financing tools. The Abundance Generation platform, a crowdfunding platform that connects people with renewable energy projects, can be useful. This is the first crowdfunding platform to be accredited by the UK's Financial Conduct Authority (FCA). The Abundance Generation allows investors to invest in a wide range of alternative energy development projects in the UK. Another crowdfunding platform is the Trillion Fund, which supports innovative renewable energy technologies. To increase its capital, the Trillion Fund can use any of the following financing methods: bonds, community share, equity, funds or loans.

However, the effectiveness of each of the proposed financial instruments can be high only if there is a developed market for AES in Ukraine, the necessary regulatory framework and a stable investment climate.

\section{Research methodology}

The issue of attracting financial resources in the field of AES is especially relevant for the budget sphere and the housing and communal sector of Ukraine, as well as for large industrial enterprises. With a view to enhancing the efficiency level of financing in the process of the implementation of renewable energy development projects, we offer a new approach to the process of optimizing the structure of the sources of funding for such projects.

We propose optimizing the structure of funding sources for renewable (alternative) energy development projects, using the structural scheme of the optimal structure of housing adapted to 
our assumptions and accordingly modified, developed at the source (Lysov 2011) and modified at the source (Kropelnyska and Kondur 2013).

We consider that the optimal structure of sources of finance for renewable energy development projects is a structure of financial resources and innovative financial instruments which at the planned expenses for the creation of capacities of the objects producing renewable energy would satisfy Ukraine's needs for increasing the share of RES in the national energy balance in accordance with the forecast of the share of energy supply from renewable sources (3.0-12.0\% by 2025 or $12.0-25.0 \%$ by 2035 ).

The structure of the potential fund for financing renewable energy development projects (hereinafter - FFREDP) consists of $\boldsymbol{M}$ types of funds of financial resources/instruments for the development of RES (direct public funding; international credit programs; other public financial resources; energy cooperatives etc.). Each type of FFREDP is characterized by different parameters, ranging from the number of programs provided by to the amount of funds allocated for their financing.

In order to determine the amount of funds to be allocated to finance alternative energy development projects, it is important to consider which source/instrument will be most in demand and will be able to optimally achieve the share of renewable energy supply according to the forecast mentioned above.

The algorithmic approach to the calculation of the integrated vector of the FFREDP structure and aggregate vectors of the structure of sources of financing for alternative energy development projects reflects the expert assessment of the importance of meeting the needs of financial support for RES development for the given forecasts.

This is the description of the order of calculations of the aggregate vector $\bar{X}_{c}=\left(x_{1}, \ldots . x_{i}, \ldots\right.$ $x_{\mathrm{M}}$ ) of the structure of sources of financing for renewable energy development projects. This vector characterizes the entire range of sources of financial support for the development of RES based on the following sources of financial resources/instruments, namely: (1) direct public funding; (2) international credit programs; (3) other public financial resources; (4) energy cooperatives; (5) green bonds; (6) project financing; (7) crowdfunding platforms.

The structure of the sources of financing renewable energy development projects should best meet the needs of the planned costs for capacity building of renewable energy facilities, which are the most crucial and meet the level of the relevant forecasts of the share of energy supply from renewable sources, i.e.

$$
\sum_{i=1}^{M}\left(x_{i}(t)-y_{i}(t)\right)^{2} \rightarrow \min
$$

where:

$$
\begin{aligned}
& y_{i}(t) \quad-\text { the need for financial resources for the } i \text { source of financial resources/instruments } \\
& \text { at time } t
\end{aligned}
$$


The aggregate index of satisfaction of the need for financing the development of RES is calculated by the formula:

$$
U_{C}(t)=\sum_{i=1}^{M} v_{i}(t) u_{i}(t)
$$

where:

$$
\begin{gathered}
v_{i}(t) \quad-\quad \begin{array}{l}
\text { the coefficient of importance of the indicator of meeting the ne- } \\
\text { eds of financing } y_{i} \text { (RES) (determined by experts), }
\end{array} \\
\sum_{i=1}^{M} v_{i}=1 ; u_{i}(t)=\frac{x_{i}(t)}{y_{i}(t)}-\text { the degree of satisfaction of the needs for funds for the } i \text { source } \\
\text { of financial resources/instrument. }
\end{gathered}
$$

In this case, the minimization of subjectivity in the accepted values of the coefficients $v_{i}(t)$ is achieved by the choice of experts (their number, competence, experience, etc.), the available a priori correct information, the number of expert assessments, etc. Additionally, the consistency of the expert opinion (answers have a small degree of scattering) can be determined by methods of probability theory.

The criterion of economic efficiency of alternative energy development can be taken as the dynamics of satisfaction $U_{c}(t)$ i $U_{c}(t+1)$, which satisfies the condition:

$$
\left.\sum_{i=1}^{M} v_{i}(t+1) u_{i}(t+1)\right\rangle \sum_{i=1}^{M} v_{i}(t) u_{i}(t)
$$

Thus, the aggregate structure of sources of financing renewable energy development projects should be the solution of the optimization problem (1)-(2). This procedure for calculating the aggregate structure of sources of financing the development of RES is necessary for a socially, environmentally oriented and financially balanced effective regional policy, taking into account the priorities of the Sustainable Development Goals until 2030.

The aggregate vector of the structure of sources of financing alternative energy development projects is based mainly on various programs/instruments of financing the development of RES. This is due in large part to the fact that the choice of program/instrument for financing renewable energy development projects determines the amount of funds to be allocated for the construction of the facilities producing energy from RES depending on the solvency of RES and the relevant forecast period (Fig. 2). In turn, the structure of financing the development of RES depends on the amount and types (by sources of origin) of the funds spent.

The choice of the source/instrument of financing is always related to the investor (RES development entity) with the uncertainty factor (risk). It should be borne in mind that the investor seeks to participate in a program that would be as accessible to them and ones in which they can obtain subsidies. 
Based on the previous assumptions, we obtain the following model of the optimal structure of sources of funding alternative energy development projects of the total potential FFREDP:

$$
\sum_{i=1}^{M} \sum_{j=1}^{K} b_{i \mathrm{j}} \times X_{i j}(t) \times Z_{i j}(t) \rightarrow \min
$$

where:

$i \quad-$ type FFREDP (index of financial resources),

$j \quad-\quad$ index of types of sources of financial resources/instruments,

$b_{i j} \quad-\quad$ the number of potential subjects of development of type $j$ RES in the $i$ form of FFREDP,

$Z_{i j}(t)$ - set of financial resources/instruments of type $i, j$ type of source of financial resource/instrument in $t$ year,

$X i j(t)$ - volume of the $i$ type of FFREDP, $j$ type of sources of financial resources/instrument in the $t$ year.

The main limitations of this model are:

- financial capabilities of RES development entities;

$\checkmark$ restrictions on the share of energy supply from RES in accordance with the forecast limits until 2025 and until 2035.

\section{Conclusions and discussion}

Summing up the study, it should be noted that the development of RES directly depends on the ability of RES producers to attract financial resources.

Unfortunately, in Ukraine there are no statistics on sources/instruments of financing in the field of RES, which does not allow presentation of the aggregate structure of sources of financing for alternative energy development projects on the basis of actual data. However, the proposed model of their optimal structure makes it possible to predict the behavior of investors - participants of the RES development in Ukraine with the accessible pool of financial resources instruments.

The approval of this model will be made within the context of the Project and Educational Center for innovation development and investment promotion in the region "Agents of Change" of Vasyl Stefanyk Precarpathian National University (AC 2021) and will allow the monitoring of RES development projects in territorial communities of the Carpathian region of Ukraine.

The model of the optimization of the structure of financing alternative energy development projects proposed by the authors can be used in the practical activity of: 
$\checkmark$ the Ministry of Energy of Ukraine (MEnU 2021) and the Ministry of Economy of Ukraine (MEcU 2021) in the formation of the state financial policy of supporting energy saving measures, including through mechanisms of reducing the cost of credit and attracting foreign grants;

$\checkmark$ the Ministry of Development of Communities and Territories of Ukraine (MDCTU 2021) in the process of (1) the formation of the state policy in the field of financial support of energy efficiency of buildings and structures of state and communal ownership, and (2) the determination of conditions of the state (budget, grant) financing through mechanisms of public-private partnership;

the State Agency for Energy Efficiency and Energy Saving of Ukraine (SAEE 2021) and the State Fund for Regional Development of Ukraine (SFRD 2021) in developing guidelines for selecting investment projects in the field of the efficient use of fuel and energy resources, energy saving, renewable energy sources and alternative fuels, etc.

The implementation and prospects of any new system of financial support for alternative energy development projects in Ukraine or its improvement depend on the basic socio-economic, ideological and legal conditions that characterize the economy of our country as a whole. After all, we are not creating something new, but only trying to adapt the world's recognized mechanisms for financial support of RES development, optimizing the structure of sources / instruments for their financing.

Only when Ukraine improves its investment climate and attracts additional investment in renewable energy development projects will this contribute to achieving the sustainable development goals set out in our state.

\section{References}

AC 2021. "Agents of Change" of Vasyl Stefanyk Precarpathian National University. [Online] http://agentyzmin.pnu.edu.ua/ua [Accessed: 2021-08-25].

BILYAVS'KY'J, M. 2020. Guidelines for the development of alternative energy in Ukraine until2030(Opiєнтири розвитку альтернативної енергетики Украӥни до 2030 р.). The Razumkov Centre [Online] https:// razumkov.org.ua/statti/oriientyry-rozvytku-alternatyvnoi-energetyky-ukrainy-do-2030r\#a12 [Accessed: 2021-08-25] (in Ukrainian).

BJARNE, S. 2018. The importance of project finance for renewable energy projects Energy Economics. Volume 69, January 2018, pp. 280-294, DOI: 10.1016/j.eneco.2017.11.006.

CMU 2017. On approval of the Energy Strategy of Ukraine for the period up to 2035 "Security, energy efficiency, competitiveness" (Про схвалення Енергетичної стратегії України на період до 2035 року “Безпека, енергоефективність, конкурентоспроможність"). [Online] https:// zakon.rada.gov.ua/laws/show/605-2017-\%D1\%80?lang=uk\#Text [Accessed: 2021-06-25] (in Ukrainian).

DEPC 2009. Directive 2009/28/EC of the European Parliament and of the Council of 23 April 2009 on the promotion of the use of energy from renewable sources and amending and subsequently repealing Directives 2001/77/EC and 2003/30/EC. [Online] https://eur-lex.europa.eu/legal-content/EN/ ALL/?uri=CELEX\%3A32009L0028 [Accessed: 2021-06-22]. 
FMEAE 2015. The Energy Transition in Buildings Platform. Federal Ministry for Economic Affairs and Energy. [Online] https://www.bmwi.de/Redaktion/EN/Textsammlungen/Energy/energy-transition -buildings-platform.html?cms_artId=1328378 [Accessed: 2021-08-25].

GF 2020. Crowdfunding for development and climate finance. Globalfields. [Online] https://www.globalfields.co.uk/insights/crowdfunding-for-development-and-climate-finance [Accessed: 2021-08-25].

Goncharuk et al. 2021 - Goncharuk, A.G., Hromovenko, K., Pahlevanzade, A. and Hrinchenko, Y. 2021. Energy poverty leap during the pandemic: the case of Ukraine. Polityka Energetyczna - Energy Policy Journal 24(2), pp. 5-18, DOI: 10.33223/epj/136521.

IRENA 2009. Statute of the International Renewable Energy Agency (IRENA). International Renewable Energy Agency. [Online] https://irena.org/-/media/Files/IRENA/Agency/About-IRENA/Statute/ IRENA_FC_Statute_signed_in_Bonn_26_01_2009_incl_declaration_on_further_authentic_versions. ashx?la=en\&hash=FAB3B5AE51B8082B04A7BBB5BDE978065EF67D96\&hash=FAB3B5AE51B8082B04A7BBB5BDE978065EF67D96 [Accessed: 2021-06-21].

IRENA 2021. Renewable Power Generation Costs in 2020. International Renewable Energy Agency. [Online] https://www.irena.org/publications/2021/Jun/Renewable-Power-Costs-in-2020 [Accessed: 2021-06-21].

KPMG 2019. Renewable energy sources in Ukraine (Відновлювані джерела енергї в Украӥні). KPMG Ukraine. [Online] https://home.kpmg/content/dam/kpmg/ua/pdf/2019/09/Renewables-Report_2019-ua.pdf [Accessed: 2021-08-25] (in Ukrainian).

MDCTU 2021. Ministry of Development of Communities and Territories of Ukraine. [Online] https:// www.minregion.gov.ua/ [Accessed: 2021-08-29].

MEcU 2021. Ministry of Economy of Ukraine. [Online] https://me.gov.ua/old/?lang=en-GB [Accessed: 2021-08-29].

MEnU 2021. Ministry of Energy of Ukraine. [Online] http://mpe.kmu.gov.ua [Accessed: 2021-08-29].

Nigam et al. 2018 - Nigam, N., Mbarek, S. and Benetti, C. 2018. Crowdfunding to finance eco-innovation: case studies from leading renewable energy platforms. Journal of Innovation Economics \& Management 26(2), pp. 195-219. [Online] https://www.cairn.info/revue-journal-of-innovation-economics-2018-2-page-195.htm [Accessed: 2021-08-25].

NRSDGU 2017. National Report "Sustainable Development Goals: Ukraine” (Національна доповідь «Цілі Сталого Розвитку: Украӥна»). [Online] https://ukraine.un.org/uk/49413-2017-nacionalna-dopovid-cili-stalogo-rozvitku-ukraina [Accessed: 2021-04-25] (in Ukrainian).

Nyenno et al. 2020 - Nyenno, I., Selivanova, N., Korolenko, N. and Truba, V. 2020. The energy policy risk management system model: theories and practices. Polityka Energetyczna - Energy Policy Journal 23(4), pp. 33-48, DOI: 10.33223/epj/127699.

RE 2020. Renewable Energy 2020: With What Ukrainians will Start Next Year. [Online] https://ua-energy.org/uk/posts/vidnovliuvana-enerhetyka-2020-z-chym-ukraintsi-uviidut-u-nastupnyi-rik [Accessed: 2021-08-25].

SAEE 2021. State support for energy saving - the program of "warm loans" State Agency for Energy Efficiency and Energy Saving of Ukraine. [Online] https://saee.gov.ua/uk/consumers/tepli-kredyty [Accessed: 2021-08-25].

SFRD 2021. State Fund for Regional Development. [Online] https://new.dfrr.minregion.gov.ua/pro-dfrr [Accessed: 2021-08-29].

SG 2019. Pioneering Poland pumps up environmental credentials and considers local green bonds. Societe Generale. [Online] https://wholesale.banking.societegenerale.com/en/insights/clients-successes/ clients-successes-details/news/pioneering-poland-pumps-environmental-credentials-and-considers-local-green-bonds/ [Accessed: 2021-08-25].

SSSU 2021. Energy consumption from renewable sources for 2007-2020. State Statistics Service of Ukraine. [Online] http://www.ukrstat.gov.ua/ [Accessed: 2021-06-25]. 
UE 2021. Without the "green" tariff: how renewable power generation is looking for new business models [Online] https://ua-energy.org/en/posts/30-07-2021-a2ce02d8-7437-4045-aefc-58557371cba8 [Accessed: 2021-08-25].

UN 2021. 17 Goals to Transform Our World. United Nations. [Online] https://www.un.org/sustainabledevelopment/sustainable-development-goals/ [Accessed: 2021-08-01].

UNCHE 1972. United Nations Conference on the Human Environment. [Online] https://www.un.org/ga/ search/view_doc.asp?symbol=A/CONF.48/14/REV.1 [Accessed: 2021-04-25].

UNDPU 2015. United Nations Development Program (UNDP) in Ukraine. [Online] https://www.ua.undp. org/content/ukraine/uk/home/sustainable-development-goals.html [Accessed: 2021-04-25].

USELF 2018. USELF - Financing of Alternative Energy by the EBRD. [Online] https://eenergy.com.ua/ korysni-porady/uself-finansuvannya-alternatyvnoyi-energetyky/ [Accessed: 2021-06-25].

ZhYBer, T. and Solopenko, T. 2020. The implementation of Ukraine's energy policy using budget programs. Polityka Energetyczna - Energy Policy Journal 23(4), pp. 91-104, DOI: 10.33223/epj/127300.

Svitlana O. Kropelnytska, Tetiana V. MaYorova

\title{
Finansowanie projektów rozwoju energetyki odnawialnej na Ukrainie
}

\author{
Streszczenie
}

Celem artykułu jest zbadanie uwarunkowań procesu pozyskiwania środków finansowych na realizację projektów rozwoju energetyki odnawialnej (alternatywnej) na Ukrainie. Autorzy dokonują przeglądu i systematyzacji źródeł finansowania oraz innowacyjnych instrumentów finansowych dostępnych dla rozwoju odnawialnych źródeł energii (OZE) w krajach rozwijających się. Na tej podstawie powstała lista zawierająca pulę środków finansowych/narzędzi rozwoju OZE dostępnych dla inwestycji na Ukrainie. Proponuje się zbudowanie modelu optymalnej struktury źródeł finansowania projektów rozwoju energetyki odnawialnej. Badania opierają się na prognozowanym harmonogramie zwiększania udziału OZE w krajowym bilansie energetycznym Ukrainy do 2035 roku. Ograniczenia związane są z brakiem faktycznych danych o źródłach/instrumentach finansowania w zakresie OZE. Model umożliwia prognozowanie wielkości środków, które trzeba przeznaczyć na finansowanie projektów rozwoju energetyki odnawialnej, przy jednoczesnej optymalizacji struktury ich potencjalnego finansowania. Oryginalność/wartość artykułu polega po pierwsze na nowatorskim zastosowaniu modelu optymalizacyjnego do prognozowania zagregowanej struktury źródeł finansowania w energetyce; po drugie, na możliwości przetestowania modelu w praktyce i monitorowania projektów rozwoju OZE w społecznościach terytorialnych regionu karpackiego Ukrainy w oparciu o projektowo-edukacyjne centrum rozwoju innowacji i inwestycji w regionie; po trzecie, proponowany model może być wykorzystany w działaniach władz i instytucji państwowych Ukrainy w celu kształtowania polityki wspierania projektów rozwoju energetyki alternatywnej.

SŁOWA KLUCZOWE: projekty rozwoju energetyki odnawialnej, środki finansowe, instrumenty finansowe, odnawialne źródła energii 